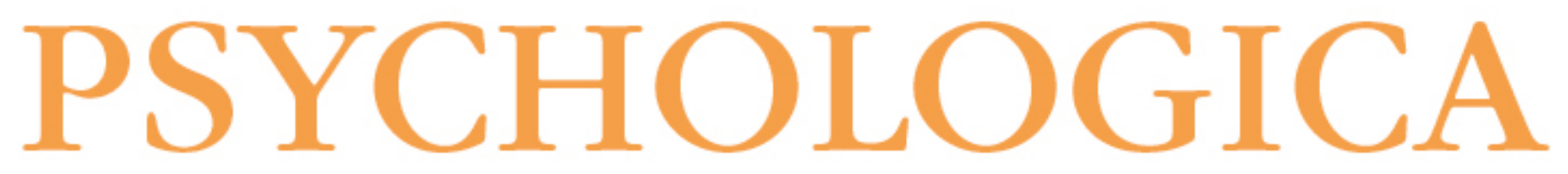

School-to-family and family-to-school enrichment in women pursuing post-secondary education

Autor(es): $\quad$ Andrade, Cláudia; Rhijn, Tricia van; Marisa, Matias

Publicado por: Imprensa da Universidade de Coimbra

URL

persistente: URI:http://hdl.handle.net/10316.2/43292

DOI: $\quad$ DOI:https://doi.org/10.14195/1647-8606_60-2_6

Accessed : $\quad$ 26-Apr-2023 14:49:58

A navegação consulta e descarregamento dos títulos inseridos nas Bibliotecas Digitais UC Digitalis, UC Pombalina e UC Impactum, pressupõem a aceitação plena e sem reservas dos Termos e Condições de Uso destas Bibliotecas Digitais, disponíveis em https://digitalis.uc.pt/pt-pt/termos.

Conforme exposto nos referidos Termos e Condições de Uso, o descarregamento de títulos de acesso restrito requer uma licença válida de autorização devendo o utilizador aceder ao(s) documento(s) a partir de um endereço de IP da instituição detentora da supramencionada licença.

Ao utilizador é apenas permitido o descarregamento para uso pessoal, pelo que o emprego do(s) título(s) descarregado(s) para outro fim, designadamente comercial, carece de autorização do respetivo autor ou editor da obra.

Na medida em que todas as obras da UC Digitalis se encontram protegidas pelo Código do Direito de Autor e Direitos Conexos e demais legislação aplicável, toda a cópia, parcial ou total, deste documento, nos casos em que é legalmente admitida, deverá conter ou fazer-se acompanhar por este aviso.

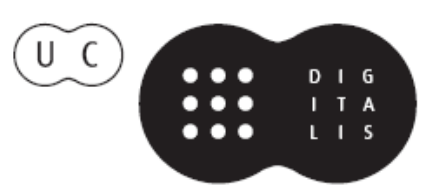




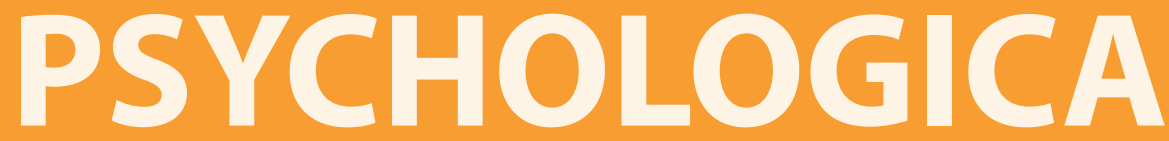




\title{
School-to-Family and Family-to-School Enrichment in Women pursuing Post-Secondary Education
}

\author{
Cláudia Andrade ${ }^{1}$ Tricia van Rhijn² e Marisa Matias ${ }^{3}$
}

\section{School-to-Family and Family-to-School Enrichment in Women pursuing Post- -Secondary Education}

\begin{abstract}
Mature and reentry female students enrolled in post-secondary education, in most cases, combine school with other life roles. Despite the growing trend to study how multiple roles may conflict with each other, evidence suggests that multiple roles can be enriching and that female non-traditional students are particularly prone to experience these benefits. Thus, we tested a school-to-family and family-to-school enrichment model, in which school dimensions (mastery experiences, low school exclusion, school satisfaction and school-to-family balance) were antecedents to school-to-family enrichment and family dimensions (family satisfaction and family-to-school balance) were antecedents of family-to-school enrichment. This model was tested, through path analysis, using 88 non-traditional Portuguese students (female student parents) enrolled in an evening undergraduate program. The model showed an adequate fit to the data, suggesting that aspects of school-to-family and family-to-school enrichment coexist. Mastery experiences and low school exclusion were associated with school-to-family enrichment while perceptions of school-to-family balance and satisfaction with the school role were not. Perceptions of family-to-school
\end{abstract}

1 College of Education, Polytechnic of Coimbra. Email: mcandrade@esec.pt

2 Department of Family Relations and Applied Nutrition, University of Guelph. Email: tricia.vanrhijm@uoguelph.ca

3 Faculty of Psychology and Educational Sciences, Center for Psychology, University of Porto. Email: marisa@fpce.up.pt 
balance were associated with family-to-school enrichment but family satisfaction was not. These findings unveil a new view on mature students enrolled at the university, pointing to the role of positive experiences at school and on school-family balance to a better interface of school and family roles.

Keywords: school-to-family enrichment; family-to-school enrichment; mastery; satisfaction with roles; role balance; non-traditional students

\section{Enriquecimento Escola-Família e Família-Escola em Mulheres a Frequentar For- mação Pós-Secundária}

\section{Resumo}

Um número crescente de mães tem vindo a enveredar por uma formação ao nível do ensino superior, distinguindo-se da população que mais comummente frequenta estes níveis de ensino, dada a necessidade de combinar os estudos com outros papéis sociais. O desempenho de múltiplos papéis tem sido debatido como essencialmente conflituoso, contudo, há evidências que o desempenho concomitante de papéis pode ser enriquecedor e que estas estudantes não-tradicionais poderão estar particularmente sensíveis a estes benefícios. Neste estudo testamos um modelo de enriquecimento na direção escola-família e na direção família-escola, em que as dimensões associadas à escola (experiências de mestria, baixa exclusão da vida escolar, satisfação com os estudos e equilíbrio na relação escola-família) foram vistas como antecedentes do enriquecimento escola-família e em que dimensões familiares (satisfação familiar e equilíbrio na relação família-escola) foram vistas como antecedentes do enriquecimento na direção família-escola. O modelo de pistas foi testado junto de 88 estudantes mães inscritas num programa de formação pós-laboral na universidade. O modelo demonstrou um bom ajustamento aos dados tendo-se verificado que as duas direções de enriquecimento coexistem. As experiências de mestria e baixos níveis de exclusão da vida escolar associaram-se ao enriquecimento na direção escola-família, enquanto perceções de equilíbrio na relação entre a família e a escola se associaram ao enriquecimento na direção oposta (família-escola). Estes resultados permitem melhor compreender o modo como estas estudantes do ensino superior vivenciam a articulação entre os seus diferentes papéis, salientando-se os aspetos positivos desta interface entre papéis familiares e académicos.

Palavras-chave: enriquecimento família-escola; enriquecimento escola-família; mestria; satisfação com o papel; equilíbrio de papéis; estudantes não-tradicionais 


\section{INTRODUCTION}

Non-traditional students, including mature and reentry students, are two key target groups for widening participation in higher education in many western countries (Butcher, Corfield, \& Rose-Adams, 2012; Devas, 2011). Portuguese higher education institutions have been following this trend with growing non-traditional student enrollment in undergraduate and graduate programs (Amorim, Azevedo, \& Coimbra, 2010). In contrast to traditional students (18-22 year olds, typically entering directly from secondary school), non-traditional students frequently blend their student role with other life roles, namely parenting. Non-traditional female students, in particular, often combine their student role with roles such as family and parenting (Quimby \& O’Brien, 2006; Sweet \& Moen, 2007). This combination of roles has been associated with negative outcomes, stemming from experiences of inter-role conflict and role strain (Home, 1998; Quimby \& O’Brien, 2006).

Despite the acknowledgement that combining multiple roles can be a source of tension and conflict, the addition of the school role can also contribute to positive outcomes like self-efficacy, positive affect and self-fulfillment (Home, 1997; Johnson \& Robson, 1999; Quimby \& O’Brien, 2006; van Rhijn, 2014). In this regard, female student parents have been found to have specific characteristics, like high motivational levels and valuable personal and family resources that contribute to these positive outcomes (Looker, 1997; van Rhijn, 2014). Some researchers have also found that pursuing post-secondary education is often described, by female non-traditional students, as a fulfillment of a "dream" that was put away due to either professional or familial responsibilities and, accordingly, attending school is often described as an enriching experience (Adams \& Corbett, 2010; Ogren, 2003).

Since the research addressing the relationship between enrollment in postsecondary education and family experiences has largely focused on the conflicting experiences faced by female students and single parents (Carney-Crompton \& Tan, 2002; Home, 1997; Quimby \& O’Brien, 2006; Van Stone et al., 1994), the exploration of potential benefits of this experience remains understudied. This paper intends to fill this gap by considering the positive relations between family and school (school-to-family enrichment and family-to-school enrichment) with a sample of Portuguese non-traditional female student parents.

\section{Post-secondary education and family life: a positive relation}

Juggling between the demands of school and family for women pursuing postsecondary education has traditionally been analyzed from a conflict perspective (i.e., 
school and family roles are viewed as competing for individual's resources such as time or energy). In fact, there is a substantial amount of empirical evidence supporting the inter-role conflict hypothesis (Hammer et al., 1998; Medved \& Heisler, 2002; Sweet \& Moen, 2007). However, more recent studies have supported that it is the quality of experiences that persons have within role contexts, rather than occupying a number of roles per se, that is the most important in predicting, among other, positive aspects in regard to life satisfaction (Haggag, Geser, Ostermann, \& Schusterschitz, 2011; Kulik, Shilo-Levin, \& Liberman, 2015). Being involved in multiple roles can have benefits in physical, mental and relationship health (Greenhaus \& Powell, 2006) that outweigh tensions due to inter-role conflict (Ahrens \& Ryff, 2006).

Grounded in the role expansion perspective (Barnett, 1998), this view holds that individuals participating in multiple roles are provided with greater opportunities and resources that can be used to promote growth and better functioning across several life domains (Grzywacz \& Marks, 2000). Thus, fulfilling one role can create energy to engage in other roles. According to Greenhaus and Powell (2006), three psychological mechanisms can account for these positive outcomes: (a) participation in different roles can have additive effects for well-being; (b) participation in one role can have buffering effects from distress in another role; and (c) participation in one role can produce positive experiences and outcomes in another role. This last mechanism refers to the concepts of facilitation, enhancement, positive spillover and enrichment. Although they refer to distinct constructs (see Carlson, Kacmar, Wayne, \& Grzywacz, 2006, and Hanson, Hammer, \& and Colton, 2006, for an analysis), these terms are similar and often used interchangeably as they respectively describe the ways in which engaging in one role can benefit experiences in the other role. Sieber (1974) and Marks (1977) were the first authors to bid a positive interaction between roles that was later designated as enrichment process. Sieber's theory of role accumulation claimed that individuals choose to participate in multiple roles for different reasons often related with rewards such as greater status and personality enrichment. Some years later, Marks' expansionist theory asserted that being involved in some roles can generate resources like increased energy, which can be directed to another life role. Greenhaus and Powell (2006) later extended these findings and delivered a comprehensive theoretical model of work-family enrichment. Greenhaus and Powell (2006) define work-family enrichment as the "extent to which experiences in one role improve the quality of life in the other role" (p.73) and consider it a bidirectional process. The model is based on the assumption that resources in a particular domain can be used to better cope with the role in the other domain, causing positive impacts on overall role performance and positive affect (i.e., improvements in the quality of life). Moreover, resources generated in one role permits improved performance in the 
other role either directly (i.e., instrumental path) or indirectly (i.e., the affective path). According to Greenhaus and Powell's model, a variety of resources are connected with work-family enrichment process, including skills (e.g., interpersonal skills and coping skills), psychological and physical resources (e.g., self-efficacy, hardiness, optimism), positive affect (e.g., enthusiasm and high energy) and socialcapital resources (e.g., networking, information), among others.

The same conceptual structure can be applied to the combination of the family and school roles. School-to-family enrichment (SFE) and family-to-school enrichment (FSE) are concepts that have similarities with those describing the enrichment process from work to family. Adapting the definition of work-family enrichment, van Rhijn and Lero (2009) propose that school-to-family enrichment is the extent to which experiences in the school role improve the quality of life in the other role, namely the family role (with family-to-school enrichment being the opposite construct, from the family role to the school role). Accordingly, SFE and FSE are defined as positive experiences and performance in the school or family role that help generate similar positive influences in the other domain.

\section{Antecedents of school-to-family and family-to-school enrichment}

Following the enrichment framework, Carlson, Kacmar, Wayne and Grzywacz (2006) claim that likely antecedents of enrichment are individual and environmental characteristics. Antecedents investigated in this study include mastery experiences, satisfaction with school, feelings of social exclusion, perceptions of balance between the school and family roles and satisfaction with family.

\section{Mastery experiences}

Fritz and Sonnentag (2006) define mastery experiences as off-job activities that offer challenging experiences and learning opportunities for the individual experience of competence and proficiency. Attaining mastery experiences is not necessarily effortless and it entails self-regulation to build up new internal resources such as skills, competencies and self-efficacy (Fritz \& Sonnentag, 2006). Because non-traditional students often have to plan carefully to cope with the demands of school and family life, they tend to value the effort they are making in order to pursue a post-secondary degree. Research by van Rhijn (2014) found that student parents felt mentally stimulated by attending post-secondary education. Given the limited amount of research attention to this topic, we decided to investigate mastery experiences as a potential antecedent and hypothesize that: 
Hypothesis 1: Mastery experiences will be positively correlated with schoolto-family enrichment.

\section{Satisfaction with school}

Tinto (1993) points out that non-traditional students quite often have other obligations outside school (e.g., family and often employment) which prevents them from having time to attend classes or formal institutional services outside 'regular' hours. Among non-traditional students such as student parents, perceived satisfaction with the school role has been linked with academic success (Zajacova, Lynch, \& Espenshade, 2005), with intrinsic motivation to learn (Carney-Crompton \& Tan, 2002), and with reports of feeling happy and stimulated by school (van Rhijn, 2014). Thus, being satisfied with the school role can be important for nontraditional students in adjusting to their school and family roles by bringing positive affect towards the student experience which, in turn, can enrich their family life. Accordingly, we hypothesize that:

Hypothesis 2: Satisfaction with school will be positively correlated with schoolto-family enrichment.

\section{Social exclusion}

Research has found that non-traditional students are often excluded from school life because of their life circumstances (Holmes, 2005). Conversely, those who had oncampus support networks emphasized the benefits of being able to talk to and empathize with other student parents (van Rhijn, 2014). Additionally, support and encouragement from school peers, which can reduce feelings of social exclusion for non-traditional students, is related to increased feelings of being part of a network (Kirk \& Dorfman, 1983), reduced stress (Sek, 1991), and overall satisfaction with the academic experience (Van Stone et al., 1994). Therefore, aligned with these findings, we expect:

Hypothesis 3: Low social exclusion will be positively correlated with schoolto-family enrichment.

\section{School-to-family balance and family-to-school balance}

Family and school roles are both recognized as being hard to combine (Home, 1997). Research by Sweet and Moen (2007) found that women returning to school face inter-role conflicts, especially when they have children. Based on Grzywacz and Carlson's (2007) definition of work-family balance "accomplishment of role-related expectations that are negotiated and shared between an individual and his/her role- 
related partners in the work and family domains" (p. 458), a similar approach can be taken to school-family and family-school balance. According to van Rhijn's (2012) findings, the ability to be a good parent to their child was very important to student parents who defined success in balancing as being connected to both their student and their parental roles. Thus, when considering how non-traditional students who are parents deal with their multiple roles, the perception of school-family balance is useful and can be linked with a positive experience that promotes family-to-school and school-to-family enrichment. Therefore, we hypothesize:

Hypothesis 4a: School-to-family balance will be positively correlated with school-to-family enrichment.

Hypothesis 4b: Family-to-school balance will be positively correlated with family-to-school enrichment.

\section{Satisfaction with family}

A study by van Rhijn (2014) found that non-traditional students receive support, including verbal encouragement, performance of household tasks and childcare from spouses/partners, children and other family members. Moreover, non-traditional students reported that having a family made it easier to prioritize and avoid wasting time by maintaining focus on their goals, even when the stress and tensions occur (van Rhijn, 2014). Based on this study, we hypothesize:

Hypothesis 5: Satisfaction with family will be positively correlated with familyto-school enrichment.

This study aims to investigate how the school and family experiences of non-traditional student mothers pursuing post-secondary education is linked to experiences of school-to-family and family-to-school enrichment. In order to investigate the research questions, a conceptual model was created that included the antecedent variables for school-to-family enrichment: school exclusion (low), school satisfaction, school-to-family balance and mastery experiences. As antecedents of family-to-school enrichment, we included family-to-school balance and satisfaction with family (see conceptual model in Figure 1). Since research examining culturally ascribed gender roles has demonstrated that combining several roles is more complex for female students than for their male counterparts (Sweet \& Moen, 2007; Zaleski et al., 1998), this study focuses on female nontraditional student parents. In addition, the work-family literature demonstrates that Portuguese women face more difficulties than men in balancing the roles of work and family due, among other factors, to their active role in dealing with family demands (Matias, Andrade, \& Fontaine, 2012). The boundaries of work 
and family roles are, therefore, more permeable for women and the boundaries of their school roles are likely similarly permeable. This permeability, however, can also be an important element in allowing positive transferences between the roles to occur. Adapting this concept, we aim to understand what factors may be linked to the enrichment process, while differentiating between family-to-school and school-to-family enrichment.

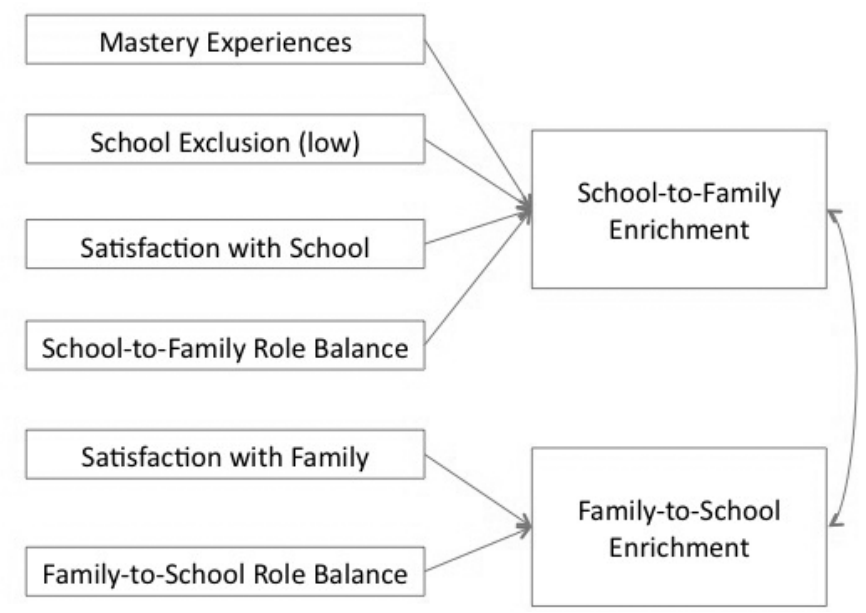

Figure 1. Conceptual model

\section{METHOD}

\section{Participants}

Participants in this study were undergraduate female students enrolled as full-time students in three different undergraduate Social Sciences and Education programs. To be eligible for this study, female students had to be aged 23 or older (criteria to be considered a non-traditional student), have children and be enrolled in classes with a full-time status at least for six months. Following ethics review, permission was obtained from professors to survey classrooms and six classes in social sciences and research methods were surveyed. A total of 88 female non-traditional students who 
fitted the above mentioned criteria for study volunteered to complete a paper and pencil survey concerning their school and family experiences, either during the class break (for students enrolled in the evening programs) or after classes. Participants were informed that their participation would be anonymous. Participants ages ranged from 27 to 52 years old $(M=36.01, S D=2.56)$. The majority were married $(67 \%), 27 \%$ were divorced and $6 \%$ were in a romantic relationship. Children's ages ranged from 2 to 18 years old $(M=7.40, S D=1.53)$, with $59 \%$ of the participants having children under 12 years old and 41\% having children older than 12 years old. Regarding employment status, 59\% reported working in a full-time job (from 35 to 40 hours/ week) and $41 \%$ in a part-time job (less than 20 hours/week). The participants reported spending an average of 19 weekly hours $(S D=8.15)$ attending classes and an average of 8 weekly hours $(S D=5.67)$ studying and preparing class team work assignments.

\section{Measures}

\section{School-to-Family and Family-to-School Enrichment}

School-to-Family and Family-to-School Enrichment were measured with 18 items adapted from Carlson, Kacmar, Holliday, Wayne and Grzywacz's (2006) self-report questionnaire scored on a 5 -point scale $(1=$ strongly disagree to $5=$ strongly agree). The word work was changed to school. Reliability for the School-to-Family Enrichment subscale was $\alpha=.82$ and Family-to-School Enrichment subscale was $\alpha=.81$. A sample item from the School-to-Family Enrichment subscale is "School helps me to understand different viewpoints and this helps me be a better family member" and from the Family-to-School Enrichment "Family helps me to gain knowledge and this helps me be a better student".

\section{Mastery Experiences}

Mastery experiences were measured with a 4 item sub-scale from the Recovery Questionnaire developed by Sonnentag and Fritz (2007). Items were scored on a 5 -point Likert scale ( $1=$ strongly disagree to $5=$ strongly agree). Cronbach's alpha was .84. A sample item from the subscale is "I do something to broaden my horizons".

\section{Satisfaction with family and school}

Two of the five subscales of the Extended Satisfaction with Life Scale (ESWLS; Alfonso, Allison, Rader, \& Gorman, 1996) were selected to be used in this study: 
the family and school satisfaction subscales. Each of the subscales consist of 5 items measured on a 7-point Likert scale from 1 (strongly disagree) to 7 (strongly agree) with higher scores indicating higher levels of satisfaction. Reliability of the subscales were .91 and .89 , for the family and school subscales, respectively. A sample item from the family subscale is "I am satisfied with my family life" and for the school subscale is "I am satisfied with my classes".

\section{School-to-family and family-to-school balance}

An adapted version of the Work-Family Balance Scale (Carlson et al., 2009) was used to measure an individual's perceived ability to manage their school and family role responsibilities. To measure school-to-family and family-to-school balance, the work-related wording was changed to school-related (i.e., work was changed to school and supervisor to instructor). The 6 items comprising the school-to-family and family-to-school balance sub-scales were rated using a 5-point Likert scale from 1 (strongly disagree) to 5 (strongly agree). Cronbach's alpha was .89. A sample item for school-to-family balance is "I am able to negotiate and accomplish what is expected of me at school and in my family" and for family-to-school balance is "I am able to accomplish the expectations that my instructors have for me as well as in my family".

\section{Social Exclusion}

Social exclusion was measured using a subscale from the Social Isolation measure (Marshall, Michaels, \& Mulki, 2007). The subscale is composed by 6 items rated using a 5-point Likert scale from 1 (strongly disagree) to 5 (strongly agree). Cronbach's alpha was .92. A sample item is "I have enough people available at school with whom I can talk to about my classes".

\section{RESULTS}

Table 1 shows the means, SDs and intercorrelations among the study variables.

Path analysis allows to evaluate simultaneously the relationship of the two dependent variables in the study, i.e., School-to-Family and Family-to-School Enrichment, on the 6 independent variables that were chosen. The main reason for choosing path analysis was due to the possibility of modelling both dependent variables at once, considering also covariance of residual errors in the measurement of dependent variables, as well as covariances in independent variables. 
Table 1.

Means, Standard Deviations and intercorrelations among the Study

\begin{tabular}{lllllllllll}
\hline Variables & $M$ & $S D$ & 1 & 2 & 3 & 4 & 5 & 6 & 7 & 8 \\
\hline 1. School-to-family enrichment & 4.12 & 1.21 & - & & & & & & & \\
2. Family-to-school enrichment & 3.81 & 1.45 & $.34^{\star *}$ & - & & & & & & \\
3. Mastery experiences & 3.52 & 0.87 & $.45^{\star *}$ & .32 & - & & & & & \\
4. Satisfaction with school & 5.51 & 0.78 & .21 & .16 & .11 & - & & & & \\
5. Satisfaction with family & 6.10 & 1.34 & .23 & .07 & .27 & .17 & - & & \\
6. School-to-family role bal- & 5.32 & 1.67 & .23 & .13 & .23 & .23 & .23 & - & & \\
ance & & & & & & & & & & \\
7. Family-to-school role bal- & 5.21 & 1.43 & .14 & .22 & .12 & .22 & .12 & .12 & - & \\
$\begin{array}{l}\text { ance } \\
\text { 8. Social exclusion }\end{array}$ & & & & & & & & & & \\
\hline
\end{tabular}
${ }^{*} \mathrm{p}<.05 .{ }^{* *} \mathrm{p}<.01$.

The proposed theoretical path model showed in Figure 1 was tested using AMOS 20 (Arbuckle, 2011). This model showed a good fit to the data (Figure2): $\chi^{2} / \mathrm{df}=$ $0.078, p<.001$, GFI $=.97$, RMSEA $<.001, \mathrm{CFI}=.97$ and TLI $=.95$. As hypothesized, mastery experiences $(\beta=.78 ; p<.001)$ and low school isolation $(\beta=.81 ; p<.001)$ were significant antecedent variables and positively related with school-to-family enrichment, while school-to-family balance $(\beta=.11 ; p=.542)$ and satisfaction with school $(\beta=.13 ; p=.134)$ were not significantly related to experiences of schoolto-family enrichment. Family-to-school balance was a significant antecedent to family-to-school enrichment $(\beta=.68 ; p<.001)$ but family satisfaction was not significantly related to experiences of family-to-school enrichment $(\beta=.11 ; p=.163)$.

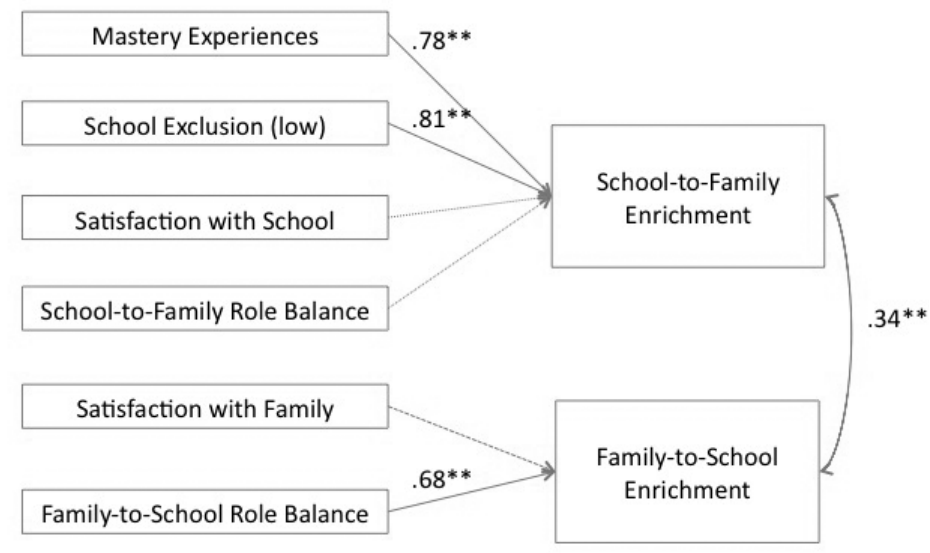

Figure 2. Empirical/Final model with significant standardized path coefficients Note: dotted arrows depict non-significant paths 


\section{DISCUSSION}

Despite the increasing participation of non-traditional students, namely student parents, in higher education, our understanding of the positive consequences of combining the student and parent roles is still limited. Some studies have begun to explore the processes through which school and family can impact each other (e.g., Van Stone et al., 2004; van Rhijn \& Lero, 2009), but investigation of how student and familial roles can enrich each other is lacking, in particular with regard to Portuguese non-traditional students. To begin addressing this gap, we tested a model of antecedents of school-to-family and family-to-school enrichment with a sample of female non-traditional students in Portugal.

This study makes an important contribution to the literature by assessing a comprehensive range of dimensions related with both the family and school contexts using school-to-family and family-to-school enrichment as outcome variables. As expected from the enrichment model, the school-based dimensions, mastery experiences and low school isolation were associated positively with school-tofamily enrichment. Our finding about social exclusion at school confirms and expands previous research demonstrating that social support, namely support that comes from school peers, can act as a buffer for stress by reducing psychological maladjustment in school (Ognibene \& Collins, 1998). It seems, therefore, that the ability of female student parents to gain support from school peers ends up having a beneficial effect in their family roles. This may occur because the support from peers provides them with a network to assure that school tasks are performed which turn into a sense of flexibility which enriches the family by having more time and energy to devote to this role. Another important finding was the link between mastery experiences and school to family enrichment. A qualitative study by van Rhijn (2014) with undergraduate student parents found that pursuing a life-long goal added motivation to learn, besides the fact that the participants wanted to be role models to their children and were motivated by other student parents who had successfully completed school. Therefore, being able to experience fulfillment and efficacy contributes to the experience of enrichment between roles. This finding clearly expands current literature on this topic and points to the importance of considering enrollment in post-secondary education as a challenge to non-traditional students that can be faced as a mastery experience. Furthermore, the results of the study suggest that female student parents, for whom conflict between their student and family roles is often the focus of research, may benefit themselves and their families from school enrollment if they have a perception that the time they are devoting to school is valuable and provides them with a sense of working towards a meaningful goal (van Rhijn, Murray, Algernon, Coyne, \& Hartley, 2014). 
Contrary to our predictions, school-to-family balance and school satisfaction were not associated with school-to-family enrichment and family satisfaction was not associated with family-to-school enrichment too. These findings suggest that the experience of satisfaction with one single role may not be enough to provide the individual with a positive transfer of resources between roles. These findings suggest that an emotional state deriving from one of the roles is not sufficient to be carried over to the other role and that more instrumental resources such as social support or mastery are more valued.

Nevertheless, in regard to family-to-school enrichment, the degree to which the individual perceives a good balance between the roles matters. The results regarding the relation between family-to-school balance and family-to-school enrichment suggest that, when non-traditional female student parents feel successful in balancing their familial and student roles, positive feelings are generated that are translated into family-to-school enrichment. As mentioned, the other two dimensions considered, school-to-family balance and school satisfaction, were not associated with school-to-family enrichment. In fact, being able to successfully balance school with family could be seen as a task that needs to be done in order to successfully deal with the demands of both roles and thus it does not provide enrichment from one role to the other. In addition, being satisfied with school does not account for school-to-family enrichment. This result is surprising and future studies are recommended to further examine and deconstruct this variable in order to tease out which aspects are most salient for female non-traditional students.

It is also important to bear in mind that our participants juggle school, family and the worker role. It is remarkable, however, that few studies have been devoted to the analysis of this reality at the country level. This study clearly unveils some aspects of this phenomenon, namely by focusing on the positive aspects of this interface. Future work with this population is strongly encouraged.

The results from the study need to be considered in the light of some limitations. First, the sample was homogenous, female student parents being drawn from a single higher education institution in Portugal. This limits the generalizability of these results. It is also important to have a large sample in future research to improve the precision of parameter estimation of the model. Future studies need to assess more diverse and gender balanced samples in order to allow for testing of possible gender differences, among other aspects. Also, the data were crosssectional and collected during mid-semester. Longitudinal research can provide a better understanding and give deeper consistency in the analysis of the family-toschool enrichment process over time and during other parts of the semester (e.g., during exams) where pressures and support may have differential impacts. Finally, as pointed out by van Rhijn and Lero (2009), the student parent population is very 
diverse. Accordingly, research with larger samples that allows for consideration of other dimensions of students' lives, like employment status, age, age of their children, type of program (full or part-time, day or evening program) should also be considered in future research.

Overall, the results suggest that enrichment models are useful perspectives from which to examine the relations between school and family, with non-traditional student parents and given the large number of non-traditional students enrolled in post-secondary education remains an important area of research. Since research addressing the positive aspects of the school-family interface is scarce, we advocate that future studies including both perspectives on inter-role conflict and enrichment are needed in order to capture a more complete picture of the combination of multiple roles in non-traditional students.

Returning to school is one means of keeping update and adapt to changing labor markets and economies. Rethinking the needs of a diverse student population like the non-traditional students is particularly important to create positive synergies between institutions that intersect with parent responsibilities (Sweet \& Moen, 2007).

Given the distinctive circumstances faced by non-traditional female student parents, even when compared to other non-traditional students, examination of the conditions that account for school and family enriching experiences is very important in order to understand their success in their roles both in school and in the family life. Research with Portuguese non-traditional students' suggests that social and academic integration is important to learning (Amorim, Azevedo, \& Coimbra, 2010). Hence, integration of study with family may play a role creating positive outcomes, providing evidence that school and family are not strictly a product of the demands, but depend on how the female students positively or negatively view those experiences.

Indeed, if increasing and widening participation in graduate programs education is an important goal for higher educational policies in Portugal (Amorim, Azevedo, \& Coimbra, 2010), having a supportive educational environment can have implications in the attraction and retention of non-traditional students.

\section{REFERENCES}

Adams, J., \& Corbett, A. (2010). Experiences of traditional and non-traditional college student: A quantitative study of experiences, motivations and expectations among undergraduate student. Methods of Social Research. Retrieved from http://www.unh.edu/sociology/index. cfm?id=ADF0DA25-E4F5-8F190AECEFEB8F59549F 
Ahrens, C. J., \& Ryff, C. D. (2006). Multiple roles and well-being: Sociodemographic and psychological moderators. Sex Roles, 55, 801-815. doi: 10.1007/s11199-006-9134-8

Amorim, J. P., Azevedo, J., \& Coimbra, J. L. (2010). On the opening of higher education institutions to new publics: the Portuguese case. Revista Portuguesa de Investigação Educacional, 9(9), 83-103.

Barnett, R. C., \& Hyde, J. S. (2001). Women, men, work, and family. American Psychologist, 56(10), 781-796. doi: 10.1037//0003-066X.56.10.781

Butcher, J., Corfield, R., \& Rose-Adams, J. (2012). Contextualized approaches to widening participation: a comparative case study of two UK universities. Widening Participation and Lifelong Learning, 13, 51-70. doi: 10.5456/WPLL.13.S.51

Carlson, D. S., Kacmar, K. M., Holliday Wayne, J., \& Grzywacz, J. G. (2006). Measuring the positive side of the work-family interface: Development and validation of a work-family enrichment scale. Journal of Vocational Behavior, 68(1), 131-164. doi: 10.1016/j.jvb.2005.02.002

Carney-Crompton, S., \& Tan, J. (2002). Support systems, psychological functioning, and academic performance of non-traditional female students. Adult Education Quarterly, 52(2), 140-154. doi: $0.1177 / 0741713602052002005$

Devas, A. (2011). Widening participation and the media student experience. Higher Education, 62(6), 815-828. doi: 10.1007/s10734-011-9421-3

Fritz, C., \& Sonnentag, S. (2006). Recovery, well-being, and performance-related outcomes: The role of workload and vacation experiences. Journal of Applied Psychology, 91(4), 936-945. doi: 10.1037/0021-9010.91.4.936

Greenhaus, J. H., \& Powell, G. N. (2006). When work and family are allies: A theory of work-family enrichment. Academy of Management Review, 31(1), 72-92. doi: 10.5465/AMR.2006.19379625

Grzywacz, J., \& Marks, N. (2000). Reconceptualising the work-family interface: An ecological perspective on the correlates of positive and negative spillover between work and family. Journal of Occupational Health Psychology, 5(1), 111-126. doi: 10.1111/j.1741-3729.2002.00028.x

Grzywacz, J. G., \& Carlson, D. S. (2007). Conceptualizing work-family balance: Implications for practice and research. Advances in Developing Human Resources, 9(4), 455-471. doi: 10.1177/152342230730548

Haggag, A., Geser, W., Ostermann, H., \& Schusterschitz, C. (2011). Relation of work family conflict and role quality on depressive symptoms in mother. Journal of Public Health, 20(6), 661-671. doi: 10.1007/s10389-012-0497-8

Hammer, L. B., Grigsby, T. D., \& Woods, S. (1998). The conflicting demands of work, family, and school among students at an urban university. Journal of Psychology, 132(2), 220-226. doi: $10.1080 / 00223989809599161$

Hanson, G. C., Hammer, L. B. \& Colton, C.L. (2006). Development and validation of a multidimensional scale of perceived work-family positive spillover. Journal of Occupational Health Psychology, 11(3), 249-65. doi: 10.1037/1076-8998.11.3.249

Home, A. M. (1997). Learning the hard way: Role strain, stress, role demands, and support in multiple-role women students. Journal of Social Work Education, 33(2), 335-347. doi: 10.1080/10437797.1997.10778874

Home, A. M. (1998). Predicting role conflict, overload and contagion in adult women university students with families and jobs. Adult Education Quarterly, 48(2), 85-97. doi: 10.1177/074171369804800204

Johnson, S., \& Robson, C. (1999). Threatened identities: The experiences of women in transition to programs of professional higher education. Journal of Community e Applied Social Psychology, 9(4), 273-288. doi: 0.1002/(SICI)1099-1298

Kirk, C., \& Dorfman, L. (1983). Satisfaction and role strain among middle age and older reentry women students. Educational Gerontology, 9(1), 15-29. doi: 10.1080/0380127830090110.1080/0380127830090102. 
Kulik, L., Shilo-Levin, S., \& Liberman, G. (2015). Multiple roles, role conflict, and sense of meaning in life among working parents. Journal of Career Development, 42(4), 263-280. doi: $10.1177 / 0894845314559428$

Looker, E. D. (1997). In search of credentials: factors affecting young adults' participation in post-secondary education. The Canadian Journal of Higher Education, 27(2/3), 1-36.

Marks, S. R. (1977). Multiple roles and role strain: Some notes on human energy, time and commitment. American Sociological Review, 42(6), 921-936.

Matias, M., Andrade, C. \& Fontaine, A. M. (2012). The interplay of gender, work and family in Portuguese families. Work, Organization, Labour and Globalization, 6(1), 11-26. doi: 10.13169/ workorgalaboglob.6.1.0011

Medved, C., \& Heisler, J. (2002). A negotiated order exploration of critical student-faculty interactions: Student parents manage multiple roles. Communication Education, 51(2), 105-120. doi: $10.1080 / 03634520216510$

Ognibene, T., \& Collins, N. (1998). Adult attachment styles, perceived social support and coping strategies. Journal of Social and Personal Relationships, 15(3), 323-345. doi: 10.1177/0265407598153002

Ogren, C. A. (2003). Rethinking the nontraditional student from a historical perspective. The Journal of Higher Education, 74(6), 640-664. doi: 10.1353/jhe.2003.0046

Quimby, J. L., \& O'Brien, K. M. (2006). Predictors of well-being among nontraditional female students with children. Journal of Counseling and Development, 84(4), 451-460. doi: 10.1002/j.15566678.2006.tb00429.x

Sieber, S. D. (1974). Toward a theory of role accumulation. American Sociological Review, 39(4), 567-578.

Sweet, S., \& Moen, P. (2007). Integrating educational careers in work and family: Women's return to school and family life quality. Community, Work \& Family, 10(2), 231-250. doi: 10.1080/13668800701270166

Tinto, V. (1993). Leaving college. Rethinking the causes and cures of student attrition (2nd ed.). Chicago: The University of Chicago Press.

Van Rhijn, T. \& Lero, D. (2009). School-Family Conflict and Enrichment in Undergraduate Student Parents. Paper presented on International Community, Work \& Family Conference, April 16-18 Utrecht, The Netherlands.

Van Rhijn, T. M. (2012). Post-secondary students with children: An investigation of motivation and the experiences of "student parents" (Doctoral dissertation). University of Guelph, Guelph, ON. Disponível em http://atrium.lib.uoguelph.ca/xmlui/handle/10214/3968

Van Rhijn, T. (2014). Barriers, Enablers, and Strategies for Success Identified by Undergraduate Student Parents. Canadian Journal for New Scholars in Education, 5(1), 1-10

Van Rhijn, T., Murray, S., Algernon, A., Coyne. T., \& Hartley, J. (2014). Partners in learning? Exploring the relationship between post-secondary study, intimacy, and sexuality for partnered mature students. Proceedings of the 2014 Annual Conference of CASAE/ACÉÉA, Brock University, Ontario, Canada, 285-288.

Van Stone, N., Nelson, J. R., \& Niemann, J. (1994). Poor single-mother college students' views on the effect of some primary sociological and psychological belief factors on their academic success. The Journal of Higher Education, 65(5), 571-584. doi: 10.2307/2943779

Zajacova, A., Lynch, S. M., \& Espenshade, T. J. (2005). Self-efficacy, stress, and academic success in college. Research in Higher Education, 46(6), 677-706. doi: 10.1007/s11162-004-4139-z

Zaleski, E. H., Levey-Thors, C., \& Schiaffino, K. M. (1998). Coping mechanisms, stress, social support, and health problems in college students. Applied Developmental Science, 2(3), 127-137. doi: 10.1207/s1532480xads0203_2 